\title{
PEMANFAATAN ASAP CAIR TERENKAPSULASI MALTODESKTRIN-KITOSAN SEBAGAI PENGAWET IKAN CAKALANG (Katsuwonus pelamis)
}

\author{
Utilization of Encapsulated Liquid Smoke Using Maltodextrin-Chitosan as a Preservative \\ Skipjack Tuna (Katsuwonus pelamis)
}

\author{
Retno Ayu Kurniasih 1 ${ }^{1)}$, Purnama Darmadji $2^{2)}$, Yudi Pranoto $3^{2)}$ \\ 1) Fakultas Perikanan dan Ilmu Kelautan, Universitas Diponegoro \\ Jl. Prof. Sudharto, S.H., Semarang 1269, Indonesia \\ ${ }^{2)}$ Fakultas Teknologi Pertanian, Universitas Gadjah Mada \\ Jl. Flora No. 1, Bulaksumur, Yogyakarta 55281, Indonesia \\ email: retno_ayuspi@yahoo.com
}

\begin{abstract}
Aims of this study were to determine the ability of the encapsulated liquid smoke using maltodextrinchitosan in inhibiting the growth of bacteria on the Skipjack Tuna during storage and determine the level of preference for Skipjack Tuna that is added with the encapsulated liquid smoke using maltodextrin-chitosan. The results showed that the encapsulated liquid smoke using maltodextrin (MD) has a moisture content (12,93 \pm $0,13) \%$, pH $(2,8 \pm 0,10)$, total acid $(2,37 \pm 0,09) \%$, total phenol $(3,05 \pm 0,01) \%$, carbonyl content $(6,97 \pm$ $0,03) \%$, while the encapsulated liquid smoke using maltodextrin-chitosan (K) has moisture content (12,09 \pm $0,07) \%, p H(2,70 \pm 0,08)$, total acid $(2,70 \pm 0,08) \%$, total phenol $(4,40 \pm 0,05) \%$, carbonyl content $(9,76 \pm$ $0,04) \%$. Utilization of the encapsulated liquid smoke using maltodextrin-chitosan $(K)$ with a concentration of $1 \%$ can inhibit the growth of bacteria on steak Skipjack Tuna during 18 hours storage at a room temperature $\left(30{ }^{\circ} \mathrm{C}\right)$. However, Utilization of the encapsulated liquid smoke using maltodextrin-chitosan $(K)$ with a concentration of 1\% didn't affect the value of sensory which includes appearance, odor, and flavor of Skipjack Tuna.
\end{abstract}

Keywords:liquid smoke, encapsulated, maltodextrin-chitosan, preservative

\section{ABSTRAK}

Tujuan penelitian ini adalah mengetahui kemampuan asap cair terenkapsulasi maltodekstrin-kitosan dalam menghambat pertumbuhan bakteri pada ikan cakalang selama penyimpanan dan mengetahui tingkat kesukaan terhadap ikan cakalang yang ditambah dengan asap cair terenkapsulasi maltodekstrin-kitosan. Hasil penelitian menunjukkan bahwa asap cair terenkapsulasi maltodekstrin (MD) memiliki kadar air (12,93 \pm $0,13) \%, \mathrm{pH} \quad 2,8 \pm 0,10$, total asam $(2,37 \pm 0,09) \%$, total fenol $(3,05 \pm 0,01) \%$, dan kadar karbonil $(6,97 \pm$ $0,03) \%$, sedangkan asap cair terenkapsulasi maltodekstrin-kitosan $(\mathrm{K})$ memiliki kadar air $(12,09 \pm 0,07) \%, \mathrm{pH}$ $2,66 \pm 0,08$, total asam $(2,70 \pm 0,08) \%$, total fenol $(4,40 \pm 0,05) \%$, dan kadar karbonil $(9,76 \pm 0,04) \%$. Pemanfaatan asap cair terenkapsulasi maltodekstrin-kitosan $(\mathrm{K})$ dengan konsentrasi $1 \%$ dapat menghambat pertumbuhan bakteri pada steak ikan cakalang selama penyimpanan 18 jam pada suhu ruang $\left(30{ }^{\circ} \mathrm{C}\right)$. Namun, pemanfaatan asap cair terenkapsulasi maltodekstrin-kitosan pada konsentrasi $1 \%$ tidak mempengaruhi nilai sensoris yang meliputi kenampakan, bau, dan rasa steak ikan cakalang.

Kata Kunci : asap cair, terenkapsulasi, maltodekstrin-kitosan, pengawet

\section{PENDAHULUAN}

Asap cair merupakan hasil pirolisa kayu atau dibuat dari campuran senyawa murni. Berdasarkan beberapa penelitian asap cair dari tempurung kelapa mengandung senyawa bioaktif, seperti fenol, karbonil, dan asam organik. Oleh karena itu, asap cair dari tempurung kelapa tidak hanya sebagai pewarna dan perasa saja, tetapi juga berpotensi untuk meningkatkan umur simpan produk makanan berprotein tinggi. Hal ini dikarenakan asap cair memiliki aktivitas antibakteri dan aktivitas antioksidan (Zuraida dkk, 2011; Saloko dkk, 2014).

Perkembangan penggunaan asap cair dari bahan kayu yang bervariasi telah berhasil digunakan sebagai alternatif metode pengawetan ikan, salah satunya adalah pengawetan ikan cakalang. Ikan cakalang 
merupakan salah satu jenis ikan yang banyak diawetkan dengan menggunakan asap di Indonesia. Swastawati dkk (2014) juga telah melakukan penelitian mengenai pengawetan ikan cakalang dengan menggunakan asap cair tempurung kelapa dan asap cair sekam padi. Hasil penelitian menunjukkan bahwa asap cair tempurung kelapa lebih efektif menurunkan nilai TPC dan meningkatkan nilai sensori ikan cakalang asap dibandingkan asap cair sekam padi.

Asap cair mudah mengalami kerusakan selama penyimpanan, yaitu terjadinya perubahan warna, teroksidasinya fenol, dan menguapnya senyawa-senyawa volatil. Oleh karena itu, perlu dikembangkan suatu metode untuk meningkatkan stabilitas asap cair selama penyimpanan. Salah satu metodenya adalah enkapsulasi asap cair. Selain itu, dengan menggunakan teknologi enkapsulasi, akan menghasilkan suatu produk berbentuk serbuk, sehingga lebih memudahkan proses distribusi. Menurut Wang dkk (2009), enkapsulasi merupakan proses melapisi partikel padatan, droplet cairan, atau gas. Selanjutnya zat aktif terbungkus dalam enkapsulan disebut inti atau core, sedangkan dinding penyalut atau enkapsulan disebut skin, shell, atau film pelindung. Saloko dkk (2012) juga telah melakukan enkapsulasi asap cair tempurung kelapa dengan menggunakan kitosan $(1,5 \% \quad b / v)$ dan maltodekstrin $(8,5 \% \quad \mathrm{~b} / \mathrm{v}) \quad$ sebagai enkapsulan. Metode yang digunakan adalah spray drying.

Pemilihan enkapsulan sangat menentukan keberhasilan proses enkapsulasi dengan menggunakan metode spray drying. Menurut Bae dan Lee (2008), maltodekstrin memiliki beberapa fungsi, yaitu bulking dan membentuk film, memiliki kemampuan mengikat rasa dan lemak, serta mengurangi permeabilitas oksigen pada matrik dinding enkapsulan. Carneiro dkk (2013) menambahkan bahwa maltodekstrin memiliki harga yang lebih murah dibandingkan gum arab, aroma dan rasa yang netral, dan viskositas yang lebih rendah. Honarkar dan Barikani (2009) juga menjelaskan bahwa kitosan juga dapat digunakan sebagai enkapsulan.

Penggunaan kitosan sebagai enkapsulan juga diharapkan dapat meningkatkan sifat fungsional asap cair sebagai pengawet. Berdasarkan penelitian Benhabiles dkk (2012), dapat menghambat pertumbuhan Escherichia coli, Pseudomonas aeruginosa, Staphylococcus aureus, Salmonella enteridis, Bacillus subtilis, Bacillus cereus, Vibriocholerae, Shigella dysenteriae, Enterobacter agglomerans, Prevotella melaninogenica, danBacteroides fragilis.

Berdasarkan uraian di atas, maka penelitian mengenai pemanfaatan asap cair terenkapsulasi maltodekstrin-kitosan sebagai pengawet ikan cakalang perlu dilakukan. Penggunaan kitosan sebagai enkapsulan diharapkan dapat melindungi senyawa bioaktif asap cair selama proses spray drying dan dapat meningkatkan daya preservatifnya. Penelitian ini bertujuan untuk mengetahui kemampuan asap cair terenkapsulasi maltodekstrin-kitosan dalam menghambat pertumbuhan bakteri pada ikan cakalang selama penyimpanan pada suhu ruang dan mengetahui tingkat kesukaan terhadap ikan cakalang yang ditambah dengan asap cair terenkapsulasi maltodekstrin-kitosan.

\section{METODE PENELITIAN}

\section{Bahan}

Bahan yang digunakan dalam penelitian ini adalah asap cair tempurung kelapa yang diperoleh dari PT Tropica Nucifera (Indonesia). Maltodekstrin dengan dextrose equivalent (DE) 10,8\% berasal dari Grain Processing Corp (Iowa, USA). Kitosan diperoleh dari Biotech Surindo (Indonesia) dengan derajat deasetilasi 91,5\%. Ikan cakalang (Katsuwonus pelamis) diperoleh dari TPI Sadeng (Gunung Kidul, Indonesia). Ada pun bahan-bahan yang digunakan untuk analisa antara lain aquades, $\mathrm{NaOH}$ (Merck, Germany), $\mathrm{HCl}$ (Merck, Germany), indikator pp (Merck, Germany), asam oksalat (Merck, Germany), standar fenol (Merck, Germany), 
$\mathrm{Na}_{2} \mathrm{CO}_{3}$ (Merck, Germany), reagen folinciocalteau (Merck, Germany), reagen 2,4-dinitrophenyl hydrazine (Merck, Germany), aseton (Merck, Germany), $\mathrm{KOH}$ (Merck, Germany), plate count agar (Oxoid, UK), $\mathrm{NaCl}$, dan alkohol.

\section{Alat}

Alat-alat yang digunakan dalam penelitian ini adalah stirrer, homogenizer (ultra turrax T50 basic, Ika-Werke, Germany) dan spray dryer (Mini B-290, Buchi, Switzerland). Alat-alat yang digunakan untuk analisis adalah spectrophotometer (Thermo Spectronic, Genesys 20, USA), labu ukur, timbangan analitik, buret, vortex (Wizard, Velp Scientifica, Italy), petridish, inkubator (MIR262, Sanyo, Japan), mikropipet (SVA-600, Accumax Smart, UK), colony counter (Stuart scientific, UK), dan autoclave (MAC-5100, Eyela, Japan).

\section{Enkapsulasi Asap Cair}

Asap cair dan enkapsulan (maltodekstrin dan kitosan) dihomogenisasi dengan kecepatan 400 rpm selama 30 menit. Rasio asap cair dan enkapsulan adalah $9: 1$, sedangkan konsentrasi kitosan yang digunakan adalah $0 \%$ daan $1 \%$ dari total enkapsulan. Selanjutnya larutan asap cair dihomogenisasi lagi dengan kecepatan 4000 rpm selama 2 menit dengan menggunakan ultra turrax homogenizer. Larutan mikropartikel dikeringkan dengan menggunakan spray dryer dengan suhu inlet $130{ }^{\circ} \mathrm{C}$ dan laju alir $5,1 \mathrm{~mL} / \mathrm{menit}$.

\section{Aplikasi Asap Cair Terenkapsulasi}

Ikan cakalang dipotong bentuk steak dengan ketebalan $1 \mathrm{~cm}$. Steak ikan cakalang yang digunakan adalah bagian perut kemudian ditambah dengan asap cair terenkapsulasi maltodekstrin (MD) dan asap cair terenkapsulasi maltodekstrin-kitosan (K) dengan konsentrasi masing-masing 1\% (b/b). Steak ikan cakalang dikemas dengan menggunakan plastik kemudian disimpan pada suhu ruang $30{ }^{\circ} \mathrm{C}$ selama 24 jam. Steak ikan cakalang tanpa penambahan asap cair terenkapsulasi (kontrol) digunakan sebagai pembanding.

\section{Metode Analisis}

Analisis yang digunakan pada penelitian ini terdiri dari analisis karakteristik kimia pada asap cair terenkapsulasi meliputi kadar air (Mehrad dkk, 2015), pH (Saloko dkk, 2013), total asam (Saloko dkk, 2013), total fenol (Senter dkk, 1989), dan total karbonil (Lappin dan Clark, 1951). Selanjutnya analisis yang digunakan untuk mengetahui daya preservatif asap cair terenkapsulasi pada ikan cakalang adalah total plate count (Alak dkk, 2010) serta dilakukan uji sensoris (Swastawati dkk, 2014) untuk mengetahui tingkat kesukaan terhadap ikan cakalang yang diawetkan dengan asap cair terenkapsulasi. Uji sensoris dilakukan dengan menggunakan 25 orang panelis tidak terlatih. Uji sensoris dilakukan dengan memberikan nilai terhadap steak ikan cakalang yang telah dikukus tanpa pemberian asap cair terenkapsulasi (kontrol), steak ikan cakalang dengan asap cair terenkapsulasi maltodekstrin, dan steak ikan cakalang dengan asap cair terenkapsulasi maltodekstrin-kitosan . Nilai untuk masingmasing parameter antara 1 sampai dengan 4 . Semakin besar nilai uji sensoris, semakin tinggi tingkat kesukaan panelis.

\section{Analisis Data}

Data yang diperoleh dari uji sensoris dianilisis non parametrik uji Kruskal Wallis dengan menggunakan SPSS versi 20. Apabila nilai Chi-square hitung lebih kecil dari Chi-square tabel, menunjukkan tidak ada perbedaan nyata pada taraf uji $95 \%$.

\section{HASIL DAN PEMBAHASAN}

\section{Karakteristik Kimia Asap Cair Terenkapsulasi}

\section{Kadar Air}

Hasil penelitian (Tabel 1) menunjukkan bahwa penambahan kitosan 
sebagai enkapsulan dapat menurunkan kadar air asap cair terenkapsulasi. Kadar air (MD) adalah $(12,93 \pm 0,13) \%$, sedangkan kadar air (K) adalah $(12,09 \pm 0,07) \%$. Rendahnya kadar air (K) dibandingkan (MD) diduga karena kitosan meningkatkan zat padat terlarut larutan asap cair sebelum spray drying. Menurut Krishnaiah dkk (2012), penambahan jumlah enkapsulan dapat meningkatkan zat padat terlarut dan mengurangi kandungan airnya. Dengan demikian, dapat menurunkan kadar air bubuk yang dihasilkan.

Penggunaan kitosan sebagai enkapsulan bersama maltodekstrin juga dapat menghambat proses kritalisasi pada permukaan partikel, sehingga air di dalam partikel dapat menguap lebih banyak selama proses spray drying. Sormoli dkk (2012) menjelaskan bahwa kitosan dapat menunda proses kristalisasi pada saat proses spray drying. Kitosan memiliki kemampuan untuk mempertahankan kelembaban selama proses spray drying. Dengan demikian, air di dalam partikel dapat menguap. Ukuran partikel yang lebih kecil juga membuat luas permukaan kontak dengan udara pengering semakin luas.

\section{2. $\mathbf{p H}$}

Penggunaan

kitosan

bersama maltodekstrin sebagai enkapsulan menyebabkan $\mathrm{pH}$ (K) lebih rendah dibandingkan dengan (MD) (Tabel 1). $\mathrm{pH}$ (K) adalah 2,66 $\pm 0,08$, sedangkan $\mathrm{pH}$ (MD) adalah 2,80 $\pm 0,08$. Hasil tersebut mengindikasikan bahwa kandungan senyawa asam organik pada (K) lebih banyak dibandingkan (MD). Hal ini sesuai dengan pernyataan Montazeri dkk (2013) serta Saloko dkk (2013), yaitu pH asap cair berkisar antara 2,3 sampai 5,7. Nilai $\mathrm{pH}$ asap cair dipengaruhi oleh kandungan asam organik, seperti asam asetat dan asam propionat.

\section{Total Asam}

Analisis total asam berdasarkan pada total asam asetat yang terdapat pada asap cair. Total asam pada MD adalah $(2,37 \pm$
$0,09) \%$ dan $\mathrm{K}$ adalah $(2,70 \pm 0,07) \%$ (Tabel 1). Berdasarkan perhitungan total asam, dapat diketahui bahwa total asam (K) lebih tinggi dibandingkan (MD). Hal ini menunjukkan bahwa kitosan dapat meningkatkan jumlah total asam yang terperangkap yang diduga disebabkan adanya interaksi antara asam asetat dengan kitosan melalui ikatan hidrogen. da Rosa dkk (2013) menjelaskan bahwa asam galat yang dienkapsulasi dengan kitosan memiliki efisiensi enkapsulasi lebih tinggi dibandingkan dengan enkapsulan $\beta$ cyclodextrin dan xanthan. Semakin tinggi nilai efisiensi enkapsulasi menunjukkan semakin banyak asam galat yang dapat dienkapsulasi. Tingginya efisiensi enkapsulasi disebabkan adanya interaksi antara asam galat dengan kitosan melalui ikatan hidrogen.

\section{Total Fenol}

Nilai total fenol pada (K) lebih tinggi dibandingkan (MD). Total fenol pada (K) adalah $(4,40 \pm 0,05) \%$, sedangkan pada (MD) adalah $\quad(3,05 \pm 0,01) \%$ (Tabel 1).Berdasarkan hasil penelitian menunjukkan bahwa maltodekstrin tidak kuat dalam melindungi fenol setelah diperangkap, sehingga banyak fenol yang hilang pada saat proses spray drying dengan suhu tinggi. Belscak-Cvitanovic dkk (2011) menambahkan bahwa kitosan terbukti dapat meningkatkan efisiensi enkapsulasi polifenol. Efisiensi enkapsulasi dihitung berdasarkan jumlah polifenol yang dapat terenkapsulasi. Efisiensi enkapsulasi terkait dengan karakteristik morfologi mikropartikel dan ketahanan terhadap panas. Dengan demikian, kitosan dapat melindungi senyawa aktif yang dienkapsulasi.

\section{Total Karbonil}

Asap cair terenkapsulasi maltodekstrin-kitosan (K) memiliki total karbonil lebih tinggi dibandingkan (MD), yaitu total karbonil $(\mathrm{K})$ adalah $(9,76 \pm 0,04)$ $\%$ dan total karbonil (MD) adalah $(6,97 \pm$ $0,03) \%$. Sama halnya dengan total asam dan total fenol, kitosan sebagai enkapsulan juga 
Tabel 1. Karakteristik kimia asap cair terenkapsulasi maltodekstrin (MD) dan terenkapsulasi maltodekstrin-kitosan (K).

\begin{tabular}{lcc}
\hline Parameter & \multicolumn{1}{c}{ MD } & K \\
\hline $\begin{array}{l}\text { Kadar air } \\
(\%)\end{array}$ & $12,93 \pm 0,13$ & $12,09 \pm 0,07$ \\
pH & $2,8 \pm 0,10$ & $2,66 \pm 0,08$ \\
$\begin{array}{l}\text { Total asam } \\
(\%)\end{array}$ & $2,37 \pm 0,09$ & $2,70 \pm 0,07$ \\
$\begin{array}{l}\text { Total fenol } \\
(\%)\end{array}$ & $3,05 \pm 0,01$ & $4,40 \pm 0,05$ \\
$\begin{array}{l}\text { Total } \\
\text { karbonil } \\
(\%)\end{array}$ & $6,97 \pm 0,03$ & $9,76 \pm 0,04$ \\
\hline
\end{tabular}

mampu melindungi senyawa karbonil pada saat pengeringan dengan menggunakan spray dryer. Honarkar dan Barikani (2009) menjelaskan bahwa kitosan dapat menghasilkan lapisan dengan struktur yang stabil, sehingga dapat melindungi senyawa bioaktif yang dilapisi.

\section{Aplikasi Asap Cair Terenkapsulasi}

\section{Total Plate Count (TPC)}

Hasil analisis TPC pada steak ikan cakalang selama penyimpanan suhu ruang $\left(30{ }^{\circ} \mathrm{C}\right)$ (Gambar 1) menunjukkan bahwa total bakteri steak ikan cakalang segar adalah $4,8 \log \mathrm{cfu} / \mathrm{g}$. Total bakteri setelah penyimpanan selama 6 jam pada steak ikan cakalang tanpa penambahan asap cair terenkapsulasi (kontrol) adalah sebesar 5,7 $\log \mathrm{cfu} / \mathrm{g}$, sedangkan pada steak ikan cakalang dengan penambahan (MD) dan (K) adalah 4,5 log cfu/g. Hasil tersebut menunjukkan bahwa steak ikan cakalang tanpa penambahan asap cair terenkapsulasi (kontrol) sudah tidak layak dikonsumsi setelah penyimpanan pada suhu ruang selama 6 jam. Berdasarkan Standar Nasional Indonesia, batas maksimal total bakteri dalam ikan segar adalah 5,69 log cfu/g (Anonim, 2006).

Total bakteri pada steak ikan cakalang dengan penambahan (MD) dan (K) mengalami penurunan setelah penyimpanan 6 jam pada suhu ruang. Hal ini menunjukkan bahwa asap cair terenkapsulasi memiliki aktivitas antimikroba. Aktivitas antimikroba asap cair terenkapsulasi disebabkan oleh senyawa fenol dan asam dalam asap cair.

Zuraida dkk (2011) menjelaskan bahwa fenol memiliki aktivitas antibakteri dengan cara menghambat pertumbuhan bakteri. Fenol dapat bereaksi dengan membran sel yang menyebabkan meningkatnya permeabilitas membran sel, inaktivasi enzim-enzim esensial, dan perusakan atau inaktivasi fungsional material genetik.

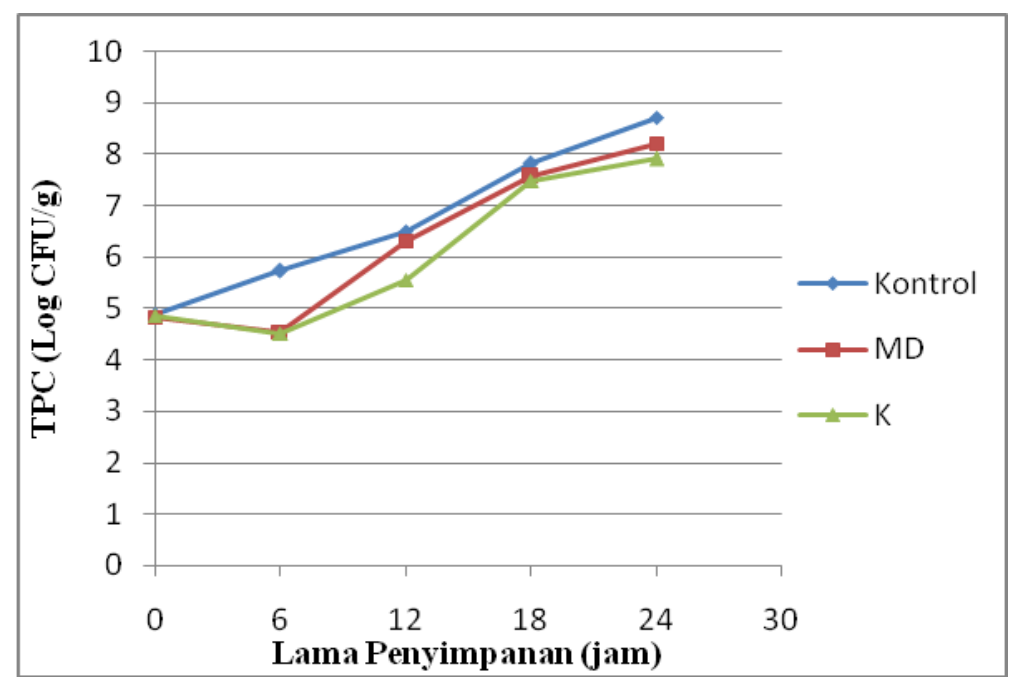

Gambar 1. Perubahan TPC pada steak ikan cakalang selama penyimpanan suhu ruang 
Achmadi dkk (2013) menambahkan bahwa asam organik dapat berfungsi sebagai pengawet pangan dengan cara menghambat pertumbuhan bakteri dalam pangan tersebut. Prinsip penghambatan tersebut adalah molekul terdisosiasi (menghasilkan $\mathrm{H}^{+}$dan anion) menyebabkan penurunan $\mathrm{pH}$ lingkungan hidupnya. Anionnya dapat menembus dinding sel bakteri, sehingga menyebabkan efek perusakan pada sel bakteri. Pada $\mathrm{pH}$ lingkungan hidup yang sangat rendah, asam organik dapat mengganggu fungsi fisiologis sel bakteri.

Steak ikan cakalang dengan (K) setelah penyimpanan pada suhu ruang selama 12 jam masih dinyatakan layak konsumsi dikarenakan total bakteri masih di bawah ambang batas maksimal total bakteri yang diijinkan pada ikan segar, yaitu 5,5 log cfu/g. Namun, steak ikan cakalang yang ditambah dengan (MD) sudah tidak layak konsumsi setelah penyimpanan pada suhu ruang selama 12 jam (Gambar 1). Berdasarkan hasil penelitian, menunjukkan bahwa dengan adanya kitosan sebagai enkapsulan juga berperan meningkatkan aktivitas antimikroba asap cair terenkapsulasi. Menurut Benhabiles dkk (2012) menyatakan bahwa kitosan memiliki aktivitas antibakteri, yaitu dengan cara mengganggu metabolisme mikroba sebagai akibat penumpukan elektrostatik pada permukaan sel mikroba. Selanjutnya, sel mikroba akan mengalami lisis.

\section{Karakteristik Sensoris}

\section{a. Kenampakan}

Kenampakan steak ikan cakalang tanpa asap cair tidak berbeda nyata $(\mathrm{p}<0,05)$ dengan steak ikan cakalang dengan asap cair terenkapsulasi. Nilai kenampakan steak ikan cakalang tanpa asap cair, dengan asap cair terenkapsulasi maltodekstrin (MD), dan terenkapsulasi maltodekstrin-kitosan (K) berturut-turut (Tabel 2) adalah 3,16 $\pm 0,89$, $3,12 \pm 1,01$, dan $2,88 \pm 1,12$. Hal ini dikarenakan penggunaan asap cair terenkapsulasi dalam jumlah sedikit, yaitu $1 \%$. Kenampakan yang tidak berbeda nyata juga disebabkan oleh warna daging ikan cakalang yang kecoklatan, sehingga warna dari asap cair terenkapsulasi tidak mempengaruhi warna daging ikan cakalang. Saloko dkk (2013) menjelaskan bahwa karbonil pada asap cair tempurung kelapa dapat bereaksi dengan gugus amino pada produk, sehingga mempengaruhi warna produk.

\section{b. Bau}

Nilai kesukaan terhadap parameter bau terhadap steak ikan cakalang dengan (K), steak ikan cakalang dengan (MD), dan steak ikan cakalang kontrol menunjukkan tidak ada perbedaan yang nyata $((\mathrm{p}<0,05)$. Nilai kesukaan terhadap parameter bau steak ikan cakalang tanpa asap cair (kontrol), steak ikan cakalang dengan (MD), dan steak ikan cakalang dengan $(\mathrm{K})$ berturut-turut adalah $2,76 \pm 0,96,3,12 \pm 0,88$, dan 3,2 $\pm 1,15$.

Hasil penelitian menunjukkan bahwa penggunaan asap cair terenkapsulasi tidak mempengaruhi bau steak ikan cakalang. Hal ini disebabkan oleh penambahan asap cair terenkapsulasi dalam jumlah sedikit, yaitu $1 \%$. Dengan demikian, bau khas daging ikan cakalang masih jelas. Meskipun demikian, berdasarkan penelitian Saloko dkk (2013), senyawa fenol memberi kontribusi nyata terhadap aroma produk yang diawetkan dengan pengasapan.

\section{c. Rasa}

Tabel 2 menunjukkan bahwa nilai kesukaan terhadap parameter rasa steak ikan cakalang dengan (K), steak ikan cakalang dengan (MD), dan steak ikan cakalang kontrol tidak berbeda nyata $(\mathrm{p}<0,05)$. Nilai kesukaan terhadap parameter rasa steak ikan cakalang tanpa asap cair (kontrol), steak ikan cakalang dengan (MD), dan steak ikan cakalang dengan $(\mathrm{K})$ berturut-turut adalah $2,84 \pm 0,85,3,12 \pm 0,92$, dan 3,16 $\pm 1,24$. 
Tabel 2. Analisis sensoris steak ikan cakalang.

\begin{tabular}{cccc}
\hline Sampel & Kenampakan & Bau & Rasa \\
\hline Kontrol & $3,16 \pm 0,89^{\mathrm{a}}$ & $2,76 \pm 0,96^{\mathrm{a}}$ & $2,84 \pm 0,85^{\mathrm{a}}$ \\
MD & $3,12 \pm 1,01^{\mathrm{a}}$ & $3,12 \pm 0,88^{\mathrm{a}}$ & $3,12 \pm 0,92^{\mathrm{a}}$ \\
$\mathbf{K}$ & $2,88 \pm 1,12^{\mathrm{a}}$ & $3,2 \pm 1,15^{\mathrm{a}}$ & $3,16 \pm 1,24^{\mathrm{a}}$ \\
\hline
\end{tabular}

Hasil penelitian menunjukkan bahwa penggunaan asap cair terenkapsulasi tidak mempengaruhi rasa steak ikan cakalang pada konsentrasi $1 \%$. Dengan demikian, ikan cakalang yang diberi penambahan asap cair terenkapsulasi, dapat menjadi bahan baku olahan lainnya tanpa ada rasa tambahan khas asap. Pada konsentrasi lebih dari $1 \%$, asap terenkapsulasi dapat mempengaruhi rasa produk yang diawetkan. Rasa khas yang diakibatkan oleh asap cair terenkapsulasi disebabkan oleh jenis dan jumlah senyawa fenol dan asam yang terkandung dalam asap cair (Vincent dkk, 2007 dan Saloko dkk, 2014).

\section{KESIMPULAN}

Pemanfaatan asap cair terenkapsulasi maltodekstrin-kitosan $\quad(\mathrm{K})$ dengan konsentrasi $1 \%$ dapat menghambat pertumbuhan bakteri pada steak ikan cakalang selama penyimpanan 12 jam pada suhu ruang $\left(30^{\circ} \mathrm{C}\right)$. Pemanfaatan asap cair terenkapsulasi maltodekstrin-kitosan pada konsentrasi $1 \%$ tidak mempengaruhi nilai sensoris yang meliputi kenampakan, bau, dan rasa steak ikan cakalang.

\section{DAFTAR PUSTAKA}

Achmadi, S.S., Mubarik, N.R., Nursyamsi, R., dan Septiaji, P. (2013). Characterization of redistilled liquid smoke of oil-palm shells and its application as fish preservatives. Journal of Applied Sciences 13(3) :401-408.

Alak, G.A., Hisar, S., Hisar, O., Kaban, G., dan Kaya, M. (2010). Microbiological and chemical properties of bonito fish (Sarda sarda) fillets packaged with chitosan film, modified atmosphere, and vacuum. Kafkas Univ Vet Fak Derg16:73-80.

Anonim. (2006). Standar Nasional Indonesia No. 01-2729.1-2006. Tentang Standar Penerimaan Ikan Segar. Badan Standarisasi Nasional, Jakarta.

Bae, E.K.dan Lee, S.J. (2008). Microencapsulation of avocado oil by spray drying using whey protein and maltodextrin. Journal of Microencapsulation25(8):549-560.

Belscak-Cvitanovic, A., Stojanovic, R., Manojlovic, V., Komes, D., Cindric, I.J., Nedovic, V., dan Bugarski, B.(2011). Encapsulation of polyphenolic antioxidants from medical plant extracts in alginatechitosan system enhanced with ascorbic acid by electrostatic extrusion. Food Research International 44(4):1094-1101.

Benhabiles, M.S., Salah, R., Lounici, H., Drouiche, N., Goosen, M.F.A., dan Mameri, N. (2012). Antibacterial activity of chitin, chitosan, and its oligomers prepared from shrimp shell waste. Food Hydrocolloids 29 :48-56.

Carneiro, H.C.F., Tonon, R.V., Grosso, C.R.F., dan Hubinger, M.D. (2013). Encapsulation efficiency and oxidative stability of flaxseed oil microencapsulated by spray drying using different combinations of wall materials. Journal of Food Engineering 115(4):443-451. 
da Rosa, C.G., Borges, C.D., Zambiazi, R.C., Nunes, M.R., Benvenutti, E.V., da Luz, S.R., D'avila, R.F., dan Rutz, J.K. (2013). Microencapsulation of gallic acid in chitosan, $\beta$-cyclodextrin, and xanthan. Industrial Crops and Product46:138-146.

Honarkar, H. dan Barikani, M. (2009). Applications of biopolymers I: chitosan. Monatsh

Chemistry140:1403-1420.

Krishnaiah, D., Sarbatly, R., dan Nithyanandam.

Microencapsulation of Morinda citrifolia L. extract by spray-drying. Chemical Engineering Research and Design 90 :622-632.

Lappin, G.R. dan Clark, L.C. (1951). Colorimetric methods for determination of trace carbonyl compound. Analytical Chemistry 23:541-542.

Mehrad, B., Shabanpour, B., Jafari, S.M., dan Pourashouri, P. (2015). Characterization of dried fish oil from Menhaden encapsulated by spray drying. International Journal of The Bioflux Society 8(1):57-69.

Montazeri, N., Oliveira, A.C.M., Himelbloom, B.H., Leigh, M.B., dan Crapo, C.A. (2013). Chemical characterization of commercial liquid smoke products. Food Science and Nutrition 1(1) :102-115.

Saloko, S., Darmadji, P, Setiaji, B., dan Pranoto, Y. (2012). Structural analysis of spray-dried coconut shell liquid smoke powder. Jurnal Teknologi dan Industri Pangan 23(2):173-179.

Saloko, S., Darmadji, P., Setiaji, B., Pranoto, Y., dan Anal, A.K. (2013). Encapsulation of coconut shell liquid smoke in chitosan-maltodextrin based nanoparticles. International Food Research Journal 20(3) :1269-1276.

Saloko, S., Darmadji, P., Setiaji, B., Pranoto, Y., dan Anal, A.K. (2014). Antioxidative and antimicrobial activities of liquid smoke nanocapsules using chitosan and maltodextrin and its application on tuna fish preservation. Food Bioscience 7 :71-79.

Senter, S.D., Robertson, J.A., dan Meredith, F.I. (1989). Phenolic compound of the mesocarp of cresthauen peaches during storage and ripening. Journal of Food Science54:1259-1268.

Sormoli, M.E., Islam, M.I., dan Langrish, T.A.G. (2012). The effect of chitosan hydrogen bonding on lactose crytallinity during spray drying. Journal of Food Engineering108(4):541-548.

Swastawati, F., Darmanto, Y.S., Sya'rani, L., Kuswanto, K.R., dan Taylor, K.D.A. (2014). Quality characteristics of smoked skipjack (Katsuwonus pelamis) using different liquid smoke. International Journal of Bioscience, Biochemistry, and Bioinformatics 4(2) : 94-99.

Vincent, V., Prost, C., dan Serot, T. (2007). Volatile aldehydes in smoked fish: analysis, methods, occurrence, and mechanisms of formation. Food Chemistry105:1536-1556.

Wang, Y., Lu, Z.X., dan Bie, X.M. (2009). Study on microencapsulation of curcumin pigments by spray drying. European Food Research and Technology 229(3):391-396.

Zuraida, I., Sukarno, dan Budijanto, S. (2011). Antibacterial activity of coconut shell liquid smoke (CS-LS) and its appplication on fish ball preservation. International Food Research Journal 18 :405-410. 